\title{
Letting Go of the Dream of Traffickers behind Bars: We can do better for exploited workers
}

\author{
Lisa Rende Taylor
}

\begin{abstract}
Response to the ATR debate proposition 'It is worth undermining the anti-trafficking cause in order to more directly challenge the systems producing everyday abuses within the global economy.'
\end{abstract}

Please cite this article as: L Rende Taylor, 'Letting Go of the Dream of Traffickers behind Bars: We can do better for exploited workers', Anti-Trafficking Review, issue 15, 2020, pp. 176-181, https://doi.org/10.14197/atr.2012201513.

Governments and businesses are duty-bound to protect and respect workers' rights. In accordance with the UN Guiding Principles on Business and Human Rights (also known as Ruggie Principles), governments, as duty bearers, must protect workers by upholding laws, regulating working conditions, managing safe and efficient labour recruitment channels, and punishing businesses that exploit workers. Businesses, as duty bearers — including employers, recruitment agencies, global brands, and retailers — must respect workers by complying with laws and other codes.

Most of the world's anti-trafficking programmes both before and after the development of the Ruggie Principles in 2011 have fallen broadly under the so-called 3 Ps: prevention, prosecution, and protection. Now, twenty years after the adoption of the UN Trafficking Protocol, enough time has passed for us to conclude that these efforts have not led to a sustained reduction in forced labour and human trafficking. ${ }^{1}$ One reason is that these efforts have been, for the most part, transactional rather than transformational. They have focused on protecting

1 M Dottridge, 'Editorial: How is the money to combat human trafficking spent?', Anti-Trafficking Review, issue 3, 2014, pp. 3-14, https://doi.org/10.14197/atr.20121431. See also: K Bryant and T Landman, 'Combatting Human Trafficking Since Palermo: What do we know about what works?', Journal of Human Trafficking, vol. 6, no. 2, 2020, pp. 119-140, https://doi.org/10.1080/23322705.2020.1690097.

This is an open-access article distributed under the terms of the Creative Commons Attribution License (CC-BY). Under the CC-BY license, the public is free to share, adapt, and make commercial use of the work. Users must always give proper attribution to the authors and the Anti-Trafficking Review. 
victims and prosecuting perpetrators rather than on changing the systems and mentalities that fundamentally deny workers their dignity. ${ }^{2}$ Related to this is the criminal justice tunnel vision underpinning most anti-trafficking programming, which focuses on only the most extreme cases. This has left the great majority of exploited workers excluded from trafficking responses while also obscuring the effects of market systems designed to put ever cheaper products into the hands of consumers. Put simply, spending millions of dollars of aid from more economically developed countries on protecting labour trafficking victims and prosecuting their exploiters in less economically developed countries makes no sense, if at the same time trillions of dollars in trade fuels demand for cheap products made by some of these very same workers and exploiters.

The addition of businesses as duty bearers in the Ruggie Principles gave labour rights practitioners new opportunities to build bridges between anti-trafficking and anti-forced labour on the one hand, and responsible sourcing and ethical trade on the other. In recent years, global brands and retailers have begun speaking more openly about the failures of businesses' risk managementoriented audit-compliance systems to uncover labour risks and abuses in their supply chains, including forced labour and human trafficking. However, for the vast majority, making the leap from talking about going beyond audits to actually trying something new has proven extremely difficult.

Most global brands and retailers have been slow to evolve their supply chain risk management and compliance practices in order to more effectively combat forced labour and human trafficking in their supply chains. In order to understand why, I looked at data from Issara Institute's recent five-year assessment of the impact of its work in empowering workers and transforming the systems and behaviours of businesses. ${ }^{3}$ Over the past five years, Issara Institute's worker voice channels operating across Cambodia, Myanmar, and Thailand ${ }^{4}$ received 143,995 calls and messages. From 2016 to 2018, these led to remediation for 81,690 individuals suffering some form of labour exploitation, most within the supply chains of our 20 global brand and retailer strategic partners. Of 81,690

2 J Chuang, 'Beyond a Snapshot: Preventing human trafficking in the global economy', Indiana Journal of Global Legal Studies, vol. 13, issue 1, Winter 2006, pp. 137-163, https:/ / doi.org/10.2979/gls.2006.13.1.137.

3 Issara Institute, Assessing Five Years of Impact and Trends in Worker Voice and Responsible Sourcing: 2014-2019, Issara Institute, Palo Alto and Bangkok, 2020, https://44f2713da205-4701-bba3-8d419653b4b6.filesusr.com/ugd/5bf36e_2977cdf991bc404aaaa 9fbf37d7d71d7.pdf.

4 These include 24-hour, multi-lingual helplines for domestic and foreign workers, Facebook (including Messenger), WhatsApp-like chat/communications apps including Line and Viber, and a Yelp-like smartphone app (Golden Dreams) for workers to rate and review their employers, recruiters, and service providers. 
workers, 19,978 met the international definition of forced labourers. Workers most commonly reported some combination of overwork (systematic, nonvoluntary overtime), underpay (cheating on wages and benefits), deception and coercion in recruitment (e.g. a promised hourly wage changed to a piece rate upon arrival), threats, abuse, and debt bondage. Remediation of these labour abuses sometimes involved government assistance, especially with less severe cases of benefits theft, social security issues, and document issues. However, for the most part, remediation came directly from the supplier, at times with the help of supply chain leverage on the part of progressive global brand and retailer partners.

These and other similar cases point to three main reasons why it has been so difficult for global brands and retailers to improve their supply chain risk management practices:

1. Many businesses are reluctant or ill-prepared to escalate or make sourcing decisions based on data other than traditional, standardised audit-compliance data, despite the inherent shortcomings identified with audits and supplier self-reported data. Most leading global brands and retailers understand how audit data is collected by auditors, primarily from employers (suppliers), and not from workers in any safe or trusted way (if at all). They also seem to understand that auditors cannot be expected to have relationships of trust with workers, or the requisite linguistic or technical expertise to uncover issues affecting workers. This means that responsible brands and retailers require another means or channel to safely uncover issues around labour recruitment or working conditions that may require remediation. This is a fundamental challenge in parts of the world such as Southeast Asia, where goods for export are often produced by foreign migrant workers who are prohibited by law to organise, form unions, or bargain collectively. However, in Issara's experience, having to deal with such nuanced and direct feedback and validation from workers is new territory for brands and retailers. Many businesses are ill-prepared or reluctant to deal with the level of responsibility and risk that this brings.

2. Many brands and retailers are wary about partnering with organisations outside of their direct supply chain (that is, outside of their supplier base). When they do, the objective has often been risk mitigation rather than remedies for labour abuses. How a business presents its brand and core values, and how it interacts with its customers all factor into this. Businesses that publicly articulate the importance of having ethical, responsible supply chains will typically be more open to supporting new models such as workerdriven solutions. Most businesses, however, are less transparent about 
their sourcing practices, and progress is hindered by legal concerns around possible liability, risk, and expectations that arise from being privy to these new sources of information. Additionally, many brands and retailers prefer to have turn-key solutions that they and their suppliers can systematically roll out without having to partner with workers' rights groups. For example, global brands and industry groups have increasingly deployed worker polling technologies into their supply chains in recent years. ${ }^{5}$ However, this has been implemented without sufficient safeguarding in place or means of ground-truthing and validation, which by its nature requires engaging with workers and worker rights groups. In addition, many brands have not committed to addressing risks and abuses that may be discovered through such technologies. A massive industry has been built around auditcompliance frameworks, bodies, and risk data collection. However, the voices of workers and validation of the labour picture by workers is worryingly absent in this landscape, leading many in the labour rights field to question the credibility of these tools or initiatives. ${ }^{6}$

\section{Retailers (much more so than brands) generally lack relationships} with the suppliers producing the goods and products they sell. Procurement and sourcing practices have shifted as competition for low prices has driven ever narrower margins in the retail space. One of the most common changes has been for retailers to transfer responsibility for meeting not only cost, volume, and quality requirements, but also social requirements upstream. Indeed, the model for many retailers has been to push responsibility for ensuring that their standards and codes of conduct are upheld onto both external auditors and the intermediary agents, importers, and other middlepersons who hold direct relationships with manufacturing, processing, and exporting suppliers. This essentially shifts many liabilities up the supply chain and introduces another duty bearer for fair labour conditions and responsible sourcing. Consumer expectations of retailers having 'clean supply chains' still remain with the retailer, but the execution and implementation of those standards has shifted over recent years to auditing bodies and intermediary importers and buyers, which has an

5 L Rende Taylor and E Shih, 'Worker Feedback Technologies and Combatting Modern Slavery in Global Supply Chains: Examining the effectiveness of remediation-oriented and due diligence-oriented technologies in identifying and addressing forced labour and human trafficking', Journal of the British Academy, vol. 7, no. s1, 2019, pp. 131-165, https://doi.org/10.5871/jba/007s1.131.

6 Ibid.; see also: L Berg, B Farbenblum, and A Kintominas, 'Addressing Exploitation in Supply Chains: Is technology and game changer for worker voice?', Anti-Trafficking Review, issue 14, 2020, pp. 47-66, https://doi.org/10.14197/atr.201220144. 
impact on how (or whether) retailers engage and collaborate in efforts to drive remediation when labour abuses are uncovered.

Where does this leave us? On the one hand, the anti-trafficking community has largely focused on transactional interventions to prevent the worst forms of abuse. On the other hand, the business community increasingly acknowledges that their sourcing practices may be perpetuating labour abuses that they have a responsibility to help eliminate, but many are reluctant to adopt new tools and partnerships that could help them do so. Above all, most businesses have yet to engage directly with workers and worker groups to validate and remediate the real issues and risks facing workers in their supply chains.

Going back to the Issara data, the metrics demonstrate that enough businesses' responses were swift and commensurate enough to remediate the exploitation of the 81,690 workers mentioned above. For example, some global brand partners stood firmly behind their codes of conduct and reinforced to suppliers that abiding only by the lower bar set by local or national laws was not sufficient to remain part of their supply chain. This supply chain leverage time and again provided sufficient pressure or encouragement for suppliers to collaborate with Issara's business and human rights team to strengthen their labour recruitment and management systems, and remediate affected workers. Unfortunately, this was not the case for all businesses. Some resisted taking a strong stance on responsibility for addressing worker-reported abuses, especially when recent audits had not successfully identified these risks. In these cases, businesses engaged in some combination of denial, turning a blind eye to threats by their supplier against workers and Issara's NGO staff, discounting and challenging workers' experiences, insisting on focusing on audit results, and foot-dragging. This suggests that the main limitation to a scalable solution to solving the wide range of abuses in global supply chains is not the ability of workers to identify them, but the commitment of business to hearing them and responding in a swift, responsible manner.

After twenty years in the anti-trafficking sector, I argue that undermining the anti-trafficking cause to more directly challenge the systems producing everyday abuses within the global economy should be a goal, if not a moral imperative, for anyone who is serious about making workers' lives better. Encouraging, advocating for, and partnering to achieve the inclusion and empowerment of worker voices and validation in businesses' efforts to identify and effectively eliminate labour risks in their supply chains is the only scalable way for the antitrafficking sector to ever disrupt the global scale of forced labour and human trafficking.

The anti-trafficking community needs to let go of the dream of governments solving the problem of human trafficking by putting exploiters behind bars. By and large, it does not happen. And when it does, very little is actually disrupted 
in the grand scheme of things. We need to dream bigger: a path to a fairer market, where the dual questions of whether workers were treated fairly in the production of goods, and whether this is credibly verified by empowered and safeguarded workers, are taken more seriously in global supply chain management.

Lisa Rende Taylor is the Founder and Executive Director of Issara Institute, a non-profit dedicated to transforming the lives of millions of workers in global supply chains through partnerships, innovation, and empowering worker voices. She has over twenty years of experience in the anti-trafficking field, having worked in the US State Department and the United Nations on sex, marriage, and labour trafficking research and programming before founding Issara Institute. Her $\mathrm{PhD}$ in human behavioural ecology developed novel predictive risk models to explore globalisation, parental decision making, and trafficking risk in rural Thailand. Email: lisa@issarainstitute.org 